\title{
Mesleki Açık Öğretim Lisesi Öğrencilerinin Örgün Eğitim Dişında Olma Nedenlerine İlişkin Görüşlerinin Değerlendirilmesi
}

\author{
Yusuf SÖZER ${ }^{1}$ \\ ${ }^{1}$ Dr., MEB Kültür Mesleki ve Teknik. Anadolu Lisesi, yusuf sozer@yahoo.com
}

Geliş Tarihi/Received: 27.10.2016 Kabul Tarihi/Accepted: 20.6.2017 e-Yayım/e-Printed: 4.7.2017

DOI: http://dx.doi.org/10.14582/DUZGEF.785

Öz

Bu çalışmanın amac1, mesleki açık öğretim lisesi öğrencilerinin örgün eğitim dışında olma nedenlerine ilişkin görüşlerini değerlendirmektir. Nitel olan bu çalışmanın verileri, Batman ili mesleki açık öğretim liselerinde öğrenim görmekte olan 145 öğrencinin yanıtladığı açık uçlu soru formları aracılığıyla toplânmıştır. Verilerin analizi sonucunda, öğrencilerin örgün eğitimden ayrılmalarının; okul kaynaklı sebepleri arasında okulun uzak olması, okulun kötü olması; çevresel sebepleri arasında mecburiyet, arkadaş yönlendirmesi; kişisel sebepleri arasında başarısızlık ve ilgisizlik gerekçeleri ile karşılaşılmıştır. Açıköğretim programına devam etme gerekçeleri arasında ise meslek sahibi olma, kolay olduğunu düşünme, kendini geliştirme ve gerçekleştirme, hem çalışıp hem okuyabilme, eğitimi tamamlama, kendine daha fazla zaman ayırabilme, evliyken okuyabilme imkânları ön plâna çıkmıştır. Çalışmada mesleki açık öğretime devam etmenin, örgün eğitim sisteminin tıkanıklıkları için önemli bir alternatif oluşturduğu ancak niteliği ile ilgili sıkıntıların da süregelen bir sorun olduğu özellikle firsat eşitsizliği mağduru öğrencilerin örgün eğitim bünyesinde eğitimlerine devam edebilmeleri yönündeki tedbirlerin geliştirilmesi gerektiği sonucuna varılmıştır.

Anahtar Kelimeler: Mesleki Açık Lise, Açık Öğretim, Örgün, Formel Eğitim

\section{Evaluation of Vocational Open High School Students' Opinions About The Reasons of Being Out of Formal Education}

\begin{abstract}
The purpose of this study is to evaluate the vocational open high school students' opinions about the reasons of being out of formal education. The data of this qualitative study, has been collected from 145 open vocational high school pupils in Batman province by open-ended question forms. By the analysis of the data, the reasons of being out of formal education are found as; school based reasons theme including far distance of the school and bad conditions of the school; environmental reasons theme including compulsory and friend orientation; personal reasons theme including failure and indifference. The reasons for attending to open vocational program are having a job, easier way of education, self development and self-actualizing, working and getting education at the same time, getting graduation, having more time for oneself, the opputunity to have education in marriage. The final result of this study is that the oppurtunity to attend to vocational open education is an important alternative for social and personal inequalities in terms of continuity of formal education, however the limitations about open education's quality is ongoing matter and measures should be improved for keeping the students in formal education particularly who suffer from the inequality of oppurtunity.
\end{abstract}

Keywords: Vocational Open Education, Open Education, Formal, Formal Education

\section{GİRİ̧̧}

Gelişmiş ülkelerin eğitim sistemlerinin dayandırıldığı başlıca ilkelerden biri eğitimde firsat eşitliğinin sağlanmasıdır. Bu ilke, eğitimsel kaynaklara ulaşabilme ya da onlardan yararlanma eşitliğini ifade eder (Tezcan, 1997:94). Ülkemiz örgün eğitim yapılanması içinde öğrenciler yaş gruplarına dayalı olarak ilkokul, ortaokul ve lise öğretiminden devlet okullarında ücretsiz yararlanma hakkına sahiptirler. Örgün eğitim, kişilerin hayata atılmadan, iş ve meslek kollarında çalışmaya başlamadan önce okul veya okul niteliği taşıyan yerlerde, genel ve özel bilgiler bakımından yetişmelerini sağlamak amacıyla belli kanunlara göre düzenlenen eğitim, formel eğitim olarak tanımlanmıştır (URL-1). Örgün eğitim yapılanması içerisinde ilk-orta-lise ve hatta üniversite öğretiminin devlet okullarında ücretsiz olarak sağlanmasına rağmen öğrencilerin eğitim sürecindeki ihtiyaçlarının bütünüyle karşılanabildiği söylenemez. Alt sosyal sınıftaki ailelerin çocukları özellikle ekonomik bakımdan çeşitli zorluklar 
yaşamaktadırlar. Bu durumdaki öğrencilere yönelik Ülkemizde bazı ilave tedbirler söz konusudur. Parasız yatılı okullar, burs olanakları, öğretmen okulları, meslek liseleri gibi okullar bu yönde belli ölçüde çözümler sağlamaktadır. Böylece yeterli olmasa da alt sosyal sınıftaki ailelerden gelen öğrenciler için eğitim yoluyla statü kazanma olanağı sağlanmaktadır (Erden, 2001:97). Bu tedbirler aynı zamanda bu öğrencilerin örgün eğitim sistemi içinde kalmalarını destekler. Ancak yine de örgün eğitim bünyesinde bulunan öğrencilerin bir bölümü çeşitli nedenlerle örgün eğitim dışına çıkmaktadır.

Bir milletin çocukları, onun gelecekteki emekçileri, yurttaşları ve liderleridir. Bu açıdan bakıldığında, eğitimde hiçbir ferdin kaybedilmemesi gerekmektedir. Bu yüzden, eğitim ve eğitimli insan kaynağını, en verimli şekilde kullanmak için, okul terki konusu üzerinde dikkatle durulmalıdır. Okul terk oranları ortaöğretim düzeyinde incelendiğinde, mesleki eğitim kurumlanında okul terkinin daha fazla yaşandığı gözlenmektedir. Bu konuda, okul terk izleme sistemi gibi bir program olmadığı için net istatistiksel veriler elde edilememiştir. Ancak Eğitim Reformu Girişimi’nin 2010 yılı Eğitim İzleme Raporuna göre mesleki ve teknik liselerdeki okul terk oranının \%9,4 olduğu ve ortaöğretim okul türlerine göre okul terk oranının en yüksek olduğu lise türlerinin mesleki ve teknik liseler olduğu değerlendirilmektedir (Taş vd., 2013:1552-1553).

Ülkemizde genç nüfus yoğunluğunun işlevsel bir biçimde yönlendirilmesinde meslek liselerinin lokomotif bir rol üstlenmesine daha fazla ihtiyaç olduğu söylenebilir. Bu yolla öğrenciler, örgün eğitim çatısı altında kalarak bir meslek alanında uzmanlaşma imkânı elde edebilmelidirler. Ne var ki, fırsat eşitsizliği mağduru bazı genç bireyler meslek liseleri seçeneğinin de dışına çıkarak örgün eğitim sistemi dışında kalmaktadırlar. Örgün eğitim sistemi dışına çıkan bireyler için zaman ve mekân yönünden nispeten daha esnek olan açık öğretim sistemi bir alternatif olarak oluşturulmuştur. Bu bağlamda, açık öğretim sistemi bünyesinde hem bir meslek kazandırmayı amaçlayan hem de firsat eşitsizliği mağduru bireyler için daha esnek imkânlar sunan mesleki açık öğretim liseleri kurulmuştur.

2015-2016 Eğitim-Öğretim yllinda ortaöğretimde yer alan öğrencilerin örgün ve açı eğitim sisteminde bulunma durumları ile Mesleki ve Teknik Örgün Liseleri ve Mesleki Açık Öğretim Liselerinde bulunma durumlarına ilişkin dağılımları sırasıyla Tablo 1 ve Tablo 2'de sunulmuştur (Milli Eğitim İstatistikleri, 2016).

Tablo 1. 2015-2016 eğitim-öğretim yılı ortaöğretim öğrencilerinin örgün ve açık eğitim sisteminde bulunma durumlarına göre dağılımları

\begin{tabular}{lcc}
\hline Ortaöğretim Öğrencileri & $\mathbf{N}$ & Yüzde \\
\hline Örgün Ortaöğretim & 4.271 .508 & $\% 73,55$ \\
Aç1k Ortaöğretim & 1.536 .135 & $\% 26,45$ \\
Toplam & $\mathbf{5 . 8 0 7 . 6 4 3}$ & $\mathbf{\% 1 0 0}$ \\
\hline
\end{tabular}

Tablo 1'de görüldüğü gibi, 2015-2016 Eğitim-Öğretim y1lı verilerine göre ortaöğretimde 5.807.643 öğrenci bulunmaktadır. Bunların 4.271.508’i örgün eğitim, 1.536.135’ i ise açık eğtitim sisteminde yer almaktadır. Ortaöğretim zorunlu eğitim kapsamında bulunmasına rağmen öğrencilerin \%26,45’inin aç1köğretim yoluyla ortaöğretim öğrenimini sürdürdüğü anlaşılmaktadır.

Tablo 2. 2015-2016 eğitim-öğretim y1lında mesleki ortaöğretimde yer alan öğrencilerin mesleki örgün ve mesleki açık ortaöğretimde bulunma durumlarına göre dağıllımları

\begin{tabular}{lcc}
\hline Mesleki Ortaöğretim Öğrencileri & $\mathbf{N}$ & Yüzde \\
\hline Mesleki Örgün Ortaöğretim & 1.754 .539 & $\% 89,68$ \\
Mesleki Açık Ortaöğretim & 201.808 & $\% 10,32$ \\
Toplam & $\mathbf{1 . 9 5 6 . 3 4 7}$ & $\mathbf{0 1 0 0}$ \\
\hline
\end{tabular}

Tablo 2'de görüldüğü gibi, 2015-2016 Eğitim-Öğretim y1lı verilerine göre Mesleki ve Teknik Eğitim Genel Müdürlüğü’ne bağlı mesleki örgün ortaöğretim kurumlarında 1.754 .539 öğrenci bulunmaktayken mesleki açık öğretim kurumlarına devam eden öğrenci sayısı ise 201.808'dir. Mesleki ortaöğretim öğrencilerinin \%10,32'sinin mesleki açık öğretim liselerinde öğrenim gördüğü anlaşılmaktadır. Bu veriler çerçevesinde, gerek genel ve gerek mesleki ortaöğretimde zorunlu eğitim çağında bulunan gençlerin belli bir bölümünün açıöğretim sistemine yönelmekte oldukları anlaşılmaktadır.

Alt sosyo-ekonomik düzeydeki ailelerden gelen ve akademik yönden başarılı olan çocuklara yönelik hem resmi hem de özel eğitim kurumlarında çeşitli burs olanakları sağlanmaktadır. Bu amaçla, devlet tarafından her yıl yapılan "Parasız Yatılııı ve Bursluluk Sınavı" ile pek çok özel kurumların sağladığı çeşitli burslar temelde akademik açıdan başarılı öğrencilerin desteklenmesi amacına yöneliktir. Ancak, meslek liselerindeki 
öğrencilerin akademik yönden nispeten başarısız oldukları değerlendirilirse bu öğrencilerin akademik başarıya odaklı pek çok burs olanağından uzak kaldıkları ortaya çıkar. Bu durum, meslek liselerinde öğrenim gören alt sosyo-ekonomik düzeydeki öğrencilerin bir bölümünün, eğitim giderleri yüzünden örgün eğitim sistemi dişına çıkmalarına yol açabilmektedir. Alt sosyo-ekonomik düzeydeki öğrenciler için mesleki öğretim bünyesinde kalmalarına imkân verecek önemli bir uygulama döner sermaye uygulamasıdır. Bu uygulama MEB Döner Sermaye İşletmeleri Çalışma Yönergesi ile düzenlenmiştir ve bu yönerge kapsamında meslek lisesi öğrencileri bir yandan üretime teşvik edilirken öte yandan üretimi teşvik primi olarak dağıtılan kârdan yararlanabilmektedir (URL-2). Düşük sosyo-ekonomik düzeydeki öğrenciler için bir kaynak anlmına gelen bu uygulamadan 2015 MEB Döner Sermaye İşletmeleri verilerine göre, mesleki örgün liselerin yalnızca \%24,6's1 yararlanmaktadır. Döner sermaye uygulamasının mesleki liselere yaygınlaşmasının özellikle düşük sosyo-ekonomik çevreden gelen öğrencilerin örgün eğitim çatısı altında eğitim hayatlarını sürdürmelerine olumlu katk1 sağlayacağ1 söylenebilir.

Mesleki eğitime yönelen bireylerin eğitim giderleri sorununa değinen Wieringen ve Attwell (1999:7), önceki eğitim sürecinde başarılı olamamış kişiler için daha esnek ve daha az maliyetli bir yaşam boyu mesleki öğrenme olanağ1 sağlanabileceğini ileri sürmüşlerdir. Ülkemizde bu tespitle uyumlu olarak hem örgün eğitim içerisindeyken süreç dışına çıkan hem de zorunlu öğrenim çağı sonrasında alternatif bir meslek edinmek isteyen bireylerin mesleki eğitim ihtiyaçlarını karşılamaya dönük olarak mesleki açı öğretim kurumlanı bulunmaktadır. Bu kurumlar kapsamında mesleki açık öğretim liseleri önemli bir yer tutmaktadır.

Mesleki açık öğretim liseleri, zorunlu lise çağında bulunan gençlerden örgün öğretim bünyesinde olup lise öğrenimi sırasında iki yıl başarısız olmaları halinde veya lise öğrenimi görmemiş/tamamlayamamış bireylerin zorunlu okul çağı (18 yaşından sonra) sonrasında gerek meslek öğrenme gerekse de lise öğrenimini tamamlama imkânı veren genellikle örgün öğretim binalarını kullanarak hafta sonu öğretim yapan ortaöğretim kurumlarıdır. Mesleki açık öğretim liselerinin amaçları, gelişmiş kitle iletişsim araçları ve yeni teknolojileri kullanarak; (a) ilköğretimi tamamlayan ancak orta öğretime devam etmeyenler ile orta öğretimden ayrllan, mezun olan ve yükseköğretimden ayrılan veya mezun olanlara farklı alanlarda öğrenim görme firsatı vererek eğitim öğretim imkânı sağlamak, (b) orta öğretim düzeyinde fırsat ve imkân eşitliğine, toplumun kültür düzeyinin yükseltilmesine ve güçlendirilmesine katkı sağlamak, (c) öğrencileri hayata ve yükseköğretime hazırlamaktır. Mesleki açık öğretim liselerinin bazı temel özellikleri şunlardır: Program ve materyaller; bilişim teknolojileri, doküman ve bunlarla ilgili diğer araçlarla desteklenir. Ĕ̆itim öğretim çalışmalarında dönem bütünlüğü esastır. Ölçme ve değerlendirme, ders geçme ve kredi esaslarına göre yapılır. Öğrencilerin istemesi ve fizikî mekânın sağlanması durumunda, bazı derslerin kurs niteliğinde yüz yüze öğretiminin yapılması sağlanır. Derslerin sınavları merkezî sistemle yapılır. Öğrenci kayıtlarında yaş sınırı yoktur, öğrenim süresi sınırsızdır. Lisede, örgün genel orta öğretim programları uygulanır (URL-3).

Mesleki açık ögretim liseleri, zorunlu okul çağı sırasında veya sonrasında çeşitli nedenlerle örgün lise eğitimine devam edememiş öğrencilerin öğrenim hayatlarını sürdürmelerine imkân vermektedir. Ancak örgün sistemde eğitim öğretmen aracıllğıyla gerçekleştirilirken açı öğretimde öğrenmeler daha çok öğrencilerin kendi kişisel gayretlerine kalmaktadır. Halbuki örgün eğitim sistemi dışına çıkmış olan bireylerin, rehberliğe ve etkileşime daha çok ihtiyaçları olduğu söylenebilir. Buna rağmen açık lise programı çerçevesinde yüz yüze eğitim olanağı oldukça sınırlıdır. Mesleki açık liselerde mesleki derslerin yüz yüze gerçekleştirilmesi yönünde tedbirler alınmakta, kültür dersleri ise öğretmensiz olarak öğrencinin kişisel gayretine kalmaktadır. Gerek üniversite ve gerekse personel alım sınavlarında kültür derslerinin ağırlığı dikkate alınırsa firsat eşitsizliği nedeniyle örgün eğitim sisteminden kopan öğrencilerin sorunlarının sürgit devam ettiği söylenebilir.

Eğitimde firsat eşitliğinin sağlanması giderek ulaşılması güç bir ideale dönüşmektedir. Bu eşitsizliğin temelinde toplumsal yapı, kazançlar, kültürel zenginlikler ve değişik toplumsal gruplar arasındaki güç dağılımı gibi unsurlar yatmaktadır. Toplumsal eşitsizliğin olduğu yerde firsatların eşitlenmesi de uzun vadeli bir çözüm sağlamayacaktır. Çünkü sistem yarışmacıdır ve yarışma mantığında birileri kazanırken diğerlerinin kaybetmesi gerçeği söz konusudur (Doğan, 2004 :97). Gerçekten de daha çok sosyal sinıf farklılıklarına temellendirilen eğitimde fırsat eşitliğini sağlamada devletlerin vatandaşlarına eğitim olanaklarını dağıtırken fırsatları eşitleme 
yönündeki tedbirleri eşitsizlikleri kalıcı bir biçimde giderememekte ve sorunu kimi zaman daha karmaşı bir hale getirebilmektedir (David ve Reid, 2007:85). Bu sorun karşısında sosyal devlet, bir yandan eşitsizlikleri gidermeye dönük olanaklar sağlamaya öte yandan bireylerin hızla değişmekte olan toplum koşullarına uyum sağlayabilecek biçimde nasıl yetiştirilebileceğine odaklanmalıdır. Bu bağlamda, mesleki eğitim çok önemli bir potansiyel çözüm alanı olarak değerlendirilebilir.

Mesleki eğitimin sosyal ve ekonomik hayat içindeki önemi dünya genelinde artmaktadır. Mesleki yeterlilikler, bireyleri, işverenleri ve hükümetleri, alt ve üst sosyal sınıflardaki tüm insanları etkilemektedir. Bu çerçevede mesleki eğitim, bireylerin tüm hayatına yayılmaya başlamış ve sürekli bir öğrenme alanı haline gelmiştir. İş ve ekonomi dünyasındaki hızlı değişim, mesleki eğitimde de hızlı bir değişimi gerektirmektedir (Moran ve Rumble, 2004:5). Özellikle mesleki eğitim bakımından eğitim programlarında temele alınan eğitim felsefelerinin bu hızlı değişimi destekleyebilecek özellikte olmasının çok önemli hale geldiği söylenebilir.

Ülkemiz eğitim programlarında, yönetmeliklerde daha çağdaş bir felsefe olarak ilerlemecilik felsefesini temele alan metinler yer alsa da uygulamada genellikle daimicilik ve esasicilik varllğını göstermiştir (Sönmez, 2002:138). İlerlemecilik okulu geleceğe hazırlık yeri olarak değil gerçek deneyimin merkezi ve yaşamın kendisi olarak görür. Oysa daimiciliğe göre, okul hayata hazırlık yeridir. Benzer biçimde esasicilik anlayışında da gerçek deneyimlerin yerine konu alanlarının bireylere özümsetilmesi temele alınır bu da yine okulu "hayatı öteleyen" bir hazırlık sürecine dönüştürür. Bu ayrımın mesleki eğitime, ilerlemecilik anlayışında okulun döner sermaye faaliyetlerinde olduğu gibi gerçek iş üretilen bir yer haline gelmesi ve öğrenci açısından işi icra ederken mesleği öğrenmesi şeklinde, daimicilik ve esasicilik anlayışında ise okulun gelecekte iş icra etmek için provalar gerçekleştirilen bir yer olması biçiminde yansıdığı söylenebilir. İş dünyasında çok hızlı değişimlerin yaşandığı günümüzde mesleki eğitimin geleceğe hazırlayıcılık anlayışıla hareket etmesi etkili sonuçlar vermeyebilir. Çünkü bugünün ihtiyaçları ile geleceğin ihtiyaçları önemli ölçüde farklılaşabilmektedir. Bu nedenle mesleki eğitimde, bireyin değişimlere-yeniliklere uyum kapasitelerinin gelişmesine odaklanılmalıdır. Bunun için bireylerin gerçek yaşam koşullarında işi icra ederek mesleği öğrenmelerine, gerçek uygulamalar yapmalarına daha fazla imkân verilebilir ve böylece iş dünyasının durumsallıklarına karşı daha etkin bir uyum kapasitesi geliştirmeleri sağlanabilir.

Dünyada mesleki eğitimde temele alınan eğitim felsefesinin izlerini taşıyan üç farklı sistem ortaya çıkmıstır. Bunlar; okul-işyeri temeline dayalı eğitim uygulayanlar, sadece okula dayalı eğitim uygulayanlar ve her iki anlayışı da benimseyen ama sürekli arayış içerisinde olan sistemlerdir (Binici ve Arı, 2004:384). Bunlardan ilki ilerlemecilik, ikincisi ise daimicilik ve esasicilik ile uyumludur. Sonuncusu ise tüm bunların girift bir hal almasıdır. Türkiye'de de yukarıda belirtilen her iki anlayış da benimsenmiştir. Ülkemizde sadece okula dayalı eğitim uygulamaları ağırlıkta olmakla birlikte okul-işyeri birlikteliğini benimseyen uygulamalar da söz konusudur.

Mesleki eğitimde döner sermaye uygulaması, öğrencilerin hem mesleki öğrenimlerinin sürdürüldügü hem de meslek alanlarına yönelik olarak gerçek iş deneyimleri kazanabildikleri bir faaliyettir. Ülkemizde döner sermaye olanaklarını kullanarak mesleki eğitimle gerçek iş üretme süreçlerini eş zamanlı olarak yürüten mesleki ve teknik liseler bulunmakla birlikte çoğunlukla mesleki liseler döner sermaye faaliyetlerine yönelmeksizin çevresel mesleki öğretim uygulamalarını zorunlu staj faaliyetleri ile sınırlayan bir mesleki prova süreci ile yetinmektedir. 2015 yll verilerine göre Ülkemizdeki 3292 mesleki ve teknik Liseden 801’i döner sermaye yoluyla iş üretmekte ve kazanç elde etmektedir. Bu kapsamda mesleki ve teknik liselerin \% 24,3’ ünün döner sermaye faaliyeti yürüttüğü buna karşılık \% 75,7’ sinin bu uygulamadan yararlanmadığı anlaşılmaktadır (MEB Döner Sermaye İşletmeleri, 2015).

Döner sermaye faaliyeti gerçekleştiren okullardaki öğrenciler elde edilen kazançtan pay almaktadırlar. Böylece, öğrenciler mesleki öğrenimleri sırasında bir yandan gerçek bir iş deneyimi yaşarken öte yandan ekonomik açıdan da desteklenmektedir. Döner sermaye uygulaması özellikle alt sosyo-ekonomik çevreden gelen öğrencilerin ekonomik sebeplerle okulu terk etme oranlarını azaltabilir.

Okul terkinin nedenlerini inceleyen araştırmaların büyük bölümü akademik başarı yetersizliği, motivasyon düşüklüğü ve bazı demografik veriler üzerinde durmuşlardır (French ve Conrad, 2001). Daha güncel 
araştırmalarda ise okul terkine ilişkin iki ya da daha çok olumsuz nedenin değişik birleşimlerini dikkate alma anlayışı hakimdir (Taylı, 2008:93). Okulu bırakma eğiliminin, nedenleri hakkında yapılan araştırmalar, okulu terk etme davranışının genel olarak eğitim sistemi ve okul koşullarının yanı sıra, sosyo-kültürel ve ekonomik koşullardan kaynaklandığına işaret etmektedir. Bununla birlikte okulu bırakma eğilimi ile ilişsili değişkenlerin her biri aynı derecede öneme ve etkiye sahip değildir (Şimşek, 2011:29). Dolayısıyla okulu bırakma nedenlerinin farklı unsurların birleşimine dayalı bir çeşitlilik arz ettiği söylenebilir. Örgün eğitim çağı dışına çıkan öğrenciler için yaşam boyu eğitim olanakları söz konusu olsa da örgün eğitim sistemindeki kadar verimli bir öğrenim sürecinin sağlanması oldukça güçtür.

Eğitim sistemi içinde ana yapılanmanın örgün eğitim olduğu dikkate alındığında mesleki eğitimde de öğrencilerin temel olarak bu eğitimi mesleki örgün eğitim yoluyla edinmeleri beklenir. Mesleki eğitim sürecinde örgün eğitim yerine mesleki açık ortaöğretim kurumlarına yönelen bireylerin koşullarının irdelenmesi mesleki örgün eğitim sisteminin tıkanıklıkları ve nitelikli işgücü kaybına yol açan sorunlarla nasıl daha etkin bir mücadele yapılabileceği konusunda önemli fikirler verebilir. Alanyazında mesleki eğitimle ilgili araştırmaların çoğunlukla örgün mesleki sistemi incelediği, mesleki açıöŏgretimle ilgili çalışmaların ise nispeten az olduğu görülmüştür. Ayrıca, mesleki açıkortaöğretime yönelmenin gerekçelerini inceleyen bir çalısma ile karşılaşılmamıştır. Bu bağlamda, öğrencilerin örgün eğitim dışına çıkarak mesleki açı liselere yönelme nedenlerinin incelenmesinin alanyazına katkı sağlayacağı değerlendirilmiş ve bu çalışmanın problem alanını oluşturmuştur.

\section{Amaç}

Bu çalışmada mesleki açı öğretim öğrencilerinin görüşlerine göre, örgün eğitim dışında olma nedenlerini, mesleki açık öğretim lisesinde öğrenim görmeye hangi gerekçelerle motive olduklarını, açık öğretimin örgün eğitime göre ne gibi avantajları veya dezavantajları olduğunu belirlemek amaçlanmıştır. Bu bağlamda, mesleki ortaöğretimde öğrencilerin öğrenimlerini sürdürmelerine yönelik olarak onlara mesleki açı öğretim yoluyla sağlanan olanaklar ile mesleki örgün eğitimin bu konudaki sınırllıkları hakkında çıkarımlar yapılmak istenmektedir. Bu amaç doğrultusunda aşağıdaki alt amaçlara yanıt aranmıştır.

Mesleki açı öğretim lisesi öğrencilerinin görüşlerine göre;

1. Mesleki açı öğretim lisesi öğrencilerinin örgün eğitimden ayrilma nedenleri nelerdir?

2. Mesleki açık öğretim lisesi öğrencilerini bu kurumda öğrenim görmeye motive eden unsurlar nelerdir?

3. Açık öğretimin örgün eğitime göre avantajları nelerdir?

4. Açık öğretimin örgün eğitime göre dezavantajları nelerdir?

\section{YÖNTEM}

$\mathrm{Bu}$ bölümde çalışmanın metodu, çalışma grubu, verilerin toplânması, verilerin analizi kısımlarına yer verilmiştir.

\section{1. Çalışmanın Metodu}

$\mathrm{Bu}$ çalışma, fenomenolojik (olgubilimsel) desenle gerçekleştirilmiştir. Çalışmada, mesleki açık lise öğrencilerinin örgün eğitimden ayrılma gerekçeleri hakkında ayrıntılı bulgulara, açı ve yeterli bir kavrayışa ulaşılmak istendiğinden olgubilimsel desen tercih edilmiştir.

\section{2. Çalışma Grubu}

Nitel çalışma sonuçları kimi zaman belirli bir evren yerine kuramsal önermelere genellenebilir. Bu tür çalışmalarda amaç, bir evrene "istatistiksel genellemeler” yapmak yerine "analitik genellemeler" yapmak, yani "kuram oluşturmak" veya "kuramsal önermelerde” bulunmaktır (Yıldırım ve Şimşek, 2005: 280). Nitel verilerin toplândığı bu çalışmada bir evrene genelleme yapmak yerine kuramsal önermelere ulaşmak amaçlanmıştır. Bu sebeple evrene genelleme amacını yansıtan evren-örneklem seçimi yerine verilerin toplândığı çalısma grubu seçimi yapılmıştır. Bu çalışmada, nitel araştırmalarda kullanılan amaçlı örnekleme yöntemlerinden tipik durum örneklemesi yoluyla çalışma grubu oluşturulmuştur. Çalışma kapsamında Batman 
il merkezinde bulunan tüm mesleki açık öğretim liselerinden birer sınıf seçilmiştir. Çalışma grubunda yer alan öğrencilerin okullara göre dağılımı Tablo 3’te sunulmuştur.

Tablo 3. Batman il merkezinde örnekleme alınan öğrencilerin okullara göre dağılımı

\begin{tabular}{lc}
\hline Okullar & $\begin{array}{c}\text { Ögrenci Sayıları } \\
\text { (N) }\end{array}$ \\
\hline Piri Reis Ticaret Meslek Lisesi & 21 \\
Zübeyde Hanım Mesleki ve Teknik Anadolu Lisesi & 29 \\
İbn-i Sina Mesleki ve Teknik Anadolu Lisesi & 23 \\
Kültür Mesleki ve Teknik Anadolu Lisesi & 33 \\
Endüstri Mesleki ve Teknik Anadolu Lisesi & 39 \\
\hline Toplam & $\mathbf{1 4 5}$ \\
\hline
\end{tabular}

Bu çalışmanın verilerinin toplânması amacıyla, 151 mesleki açık öğretim lisesi öğrencisine açık uçlu soru formları dağıtılmıştır. Bu formlardan 6 tanesi özensiz yanıtlandığı/yanıtsız bırakıldığı için iptal edilmiştir. Geriye dönen formların 145’i geçerli bulunmuş ve Tablo 3’te dağılımı okullarına göre dağılımı sunulmuştur.

\subsection{Verilerin Toplânması}

Çalışmada araştırmacı tarafından çalışmanın amacına yönelik olarak 4 açık uçlu soru içeren bir soru formu hazırlanmıştır. Bu süreçte alanyazın incelenmiş ve çalışmanın amacı doğrultusunda aday sorular üretilerek bir açık uçlu soru havuzu oluşturulmuştur. Araştırma probleminin psikolojik ve sosyolojik yönlerinin önemi dikkate alınarak aday sorular Batman Üniversitesi Sosyoloji ve Psikoloji bilim dalları uzmanlarının görüşlerine sunulmuştur. Aday sorular, yapılan değerlendirmeler ışı̆̆ında araştırmanın amacına uygun olacak biçimde dört açık uçlu soruya indirgenmiştir. Soru formundaki herbir soru bu çalışmanın belirli bir alt amacına yönelik verileri sağlayacak biçimde hazırlanmıştır. Dolayısıyla çalışmadaki dört alt amaç için veri toplamaya yönelik dört açık uçlu soru hazırlanmıştır.

Soru formları, Tablo 3’te dağılımı sunulan 5 ayrı mesleki ve teknik anadolu lisesinde mesleki açıöğretim lisesi programına kayıtlı olarak öğrenimlerini sürdüren 151 öğrenciye “yüzyüze eğitim” aldıkları günlerde dağıtılmıştır. Öğrencilerin konu ile ilgili görüş ve düşüncelerini daha geniş bir zaman içerisinde yanıtlamalarına imkân vermek böylece zaman darlığından ötürü unutma, heyecan gibi nedenlerle ortaya çıkabilecek veri kayb1 riskini azaltmak ve öte yandan daha çok sayıda öğrenciden veri toplayabilmek amacıyla görüşme yöntemi yerine öğrencilerden cevaplarını soruların altındaki boşluklara açıklayıcı biçimde yazmaları istenmiş ve formlar birgün sonra toplanmışır. Soru formunda her sorunun altında yeterince boşluk bırakılmasına özen gösterilmiştir. Bu yolla 151 formun tümü öğrenciler tarafından yazılı olarak cevaplânmıştır.

\subsection{Verilerin Analizi}

Veri toplama aracında bulunan 4 açı uçlu sorunun her biri ayrı ayrı içerik analizine tabi tutulmuştur. Sorulara verilen yanıtlar okunarak kodlar oluşturulmuş, kodların gözlenme sıklıkları belirlenerek de temalar oluşturulmuştur. Çalışmada gerçekleştirilen kodlamaların güvenirliğinin sağlanması amacıyla kodlayıcı güvenirliği yöntemi kullanılmıştır. Kodlayıcı güvenirliği için sorulara ilişkin cevap metinleri çalışmayı gerçekleştiren araştırmacı ve yardımcı bir araştırmacı tarafından ayrı ayrı kodlanmış ve kodlamaların uyumu incelenmiştir. Bu incelemede kodlayıcı güvenirliği için aşağıda verilen uzlaşı yüzdesi bağıntısı kullanılmıştır (Krippendorf, 2011: 1):

Kodlayıcı Güvenirliği = (Kodlayıcılar arasında uzlaşılan kod sayısı)/(Tüm Kod Sayısı)

\section{Bağınt1-1}

Bu çalşsmada kodlayıcı güvenirliği 0,89 bulunmuştur. Bu sonuca göre, yapılan kodlamaların tutarlı olduğuna karar verilmiştir. Ardından görüş ayrıllğı olan kodlar üzerine ikinci kodlayıcı ile tartışılarak uzlaşılmış ve uygun görülen temalar altına yerleştirilmiştir. Oluşturulan temalar aracılığıyla araştırmanın alt amaçları yanıtlanmiştır.

Araştırma sonuçlarının okuyucu açısından anlam kazanmasını kolaylaştırmak amacıyla yer yer doğrudan alıntılar (öğrenci görüşleri) sunulmuş, durumun ayrıntılı betimlemeleri yapılmışstır. Doğrudan alıntılanan öğrenci görüşleri italik olarak verilmiştir. 


\section{BULGULAR}

$\mathrm{Bu}$ bölümde araştırmanın alt amaçlarına yönelik toplanan verilerin analizi sonucu elde edilen bulgular sunulmuştur.

\subsection{Birinci Alt Amaca İlişkin Bulgular}

Araştırmanın birinci alt amac1, "Mesleki açık öğretim lisesi öğrencilerinin örgün eğitimden ayrılma nedenleri nelerdir?” biçimindeydi. Bu alt amaca ilişkin olarak "Okul Kaynaklı Sebepler”, "Kişisel Sebepler”, "Çevresel-Toplumsal Sebepler”, "Diğer Sebepler” temaları oluşturulmuştur.

“Okul Kaynaklı Sebepler” temasına ilişkin öğrenci görüşlerini gösteren kodlar ve frekanslar Tablo 4' te sunulmuştur.

Tablo 4. Okul kaynaklı sebepler

\begin{tabular}{lc}
\hline Kodlar & $\begin{array}{c}\text { Frekans } \\
\text { (f) }\end{array}$ \\
\hline Okulun uzak olması & 5 \\
Okulun kötü olması & 4 \\
Eğitim sisteminin kötü işleyişi & 1 \\
Okulda başörtüsünün yasak olması & 1 \\
\hline Toplam & $\mathbf{1 1}$ \\
\hline
\end{tabular}

Tablo 4'te görüldüğü gibi, örgün eğitimden ayrılmanın gerekçeleri arasında okul kaynaklı sebeplere toplam 11 ögrrencinin ifadesinde rastlanmıştır. Bunlardan 5’i okulun uzak olması, 4’ü okulun kötü olması, 1’i eğitim sisteminin kötü işleyişi ve 1'i de başörtüsünün yasak olması sebebiyle örgün eğitimden ayrılarak mesleki açı öğretim lisesine yöneldiğini ifade etmiştir.

"Kişisel Sebepler" temasına ilişkin kodlar ve frekanslar Tablo 5’te sunulmuştur.

Tablo 5. Kişisel sebepler

\begin{tabular}{lc}
\hline Kodlar & $\begin{array}{c}\text { Frekans } \\
\text { (f) }\end{array}$ \\
\hline Başarısız olma & 27 \\
Ilgisizlik & 11 \\
Özel sebepler & 8 \\
Okulu sevmeme & 5 \\
Devamsılılk & 3 \\
Ergenlik dönemi & 3 \\
Hedefsizlik & 2 \\
Hastalik & 2 \\
Psikolojik nedenler & 1 \\
Sorumsuzluk & 1 \\
Okuldan atılma & 1 \\
\hline Toplam & $\mathbf{6 4}$ \\
\hline
\end{tabular}

Tablo 5’ te görüldüğü gibi, toplam 64 öğrencinin ifadesinde örgün eğitimden ayrllma gerekçesi olarak kişisel kaynaklı sebepler ileri sürülmüştür. Bunlardan 27'si başarısız olma, 11’i ilgisizlik, 8’i özel sebepler,5’i okulu sevmeme, 3’ü devamsızlık, 3'ü ergenlik dönemi, 2'si hedefsizlik, 2'si hastalık, 1'i psikolojik nedenler, 1'i sorumsuzluk, 1’i de okuldan atılma sebebiyle örgün eğitimden ayrılarak mesleki açık öğretim lisesine yöneldiğini ifade etmiştir.

"Çevresel-Toplumsal Sebepler" temasına ilişkin kodlar ve frekanslar Tablo 6'da sunulmuştur.

Tablo 6. Çevresel-toplumsal sebepler

\begin{tabular}{lc} 
Tablo 6. Çevresel-toplumsal sebepler & \\
\hline Kodlar & $\begin{array}{c}\text { Frekans } \\
\text { (f) }\end{array}$ \\
\hline Aile içi sebep & 37 \\
Arkadaş çevresi & 11 \\
Şartların uygun olmaması & 11 \\
İşte çalışma & 4 \\
Şehirden ayrılma & 4 \\
Köyde yaşanıldı̆̆ı için & 3 \\
Akraba baskııı & 2 \\
Zorunlu evlilik & 1 \\
Teknoloji yetersizliği & 1 \\
\hline Toplam & $\mathbf{7 4}$ \\
\hline
\end{tabular}

Tablo 6’da görüldüğü gibi, örgün eğitimden ayrılma gerekçeleri arasında çevresel sebeplere toplam 74 öğrenci ifadesinde rastlanmıştır. Bunlardan 37'si aile içi sebep, 11’i arkadaş çevresi, 11'i şartların uygun olmaması, 4'ü işte çalışma, 4'ü şehirden ayrılma, 3’ü köyde yaşanıldığı için, 2'si akraba baskısı, 1'i zorunlu 
evlilik, 1’i teknoloji yetersizliği, sebebiyle örgün eğitimden ayrılarak mesleki açı öğretim lisesine yöneldiğini ifade etmiştir.

Tablo 7: Diğer sebepler

\begin{tabular}{lc}
\hline Kodlar & $\begin{array}{c}\text { Frekans } \\
\text { (f) }\end{array}$ \\
\hline 2 y1l sınavsız geçiş hakkı olduğu & 1 \\
Avantajlı olduğu düşünüldüğü için & 1 \\
\hline Toplam & $\mathbf{2}$ \\
\hline
\end{tabular}

Tablo 7’de görüldüğü gibi, iki öğrenciden biri 2 yıl sınavsız geçiş hakk1 olduğu için diğeri ise avantajlı olduğunu düşündüğü için örgün eğitimden ayrılarak mesleki açık öğretim lisesine yöneldiğini ifade etmiştir. Aşağıda bazı mesleki açık lise öğrencilerinin örgün eğitimden kopma nedenlerine ilişkin görüşlerine yer verilmiştir.

Ö-1: "Ben de bir meslek sabibi olmak istediğim için." ifadesi dikkat çekicidir. Örgün eğitim dıșına çıkma nedeni olarak bir meslek sahibi olmak istediğim için yanıtının verilmesi, mesleki örgün sistemin tıkanıklığını ortaya koyan bir ipucu olabilir. Mesleki örgün eğitim kurumlarının temel olarak öğrencilere meslek kazandırmayı amaçlamasına rağmen bunun mesleki açı ögretim alternatifine yönelmek bireyin bu esnada karşılanamayan ihtiyaçları olduğunu gösteriyor olabilir.

Aşağıda sunulan bazı öğrenci ifadeleri ise örgün eğitimden kopma nedenlerini ortaya koyan firsat eşitsizliklerini yansıtmaktadır.

Ö-5: "Kalaballk aile olduğumuฉdan liseye devam edemedim." çok kardeşli kalabalık aileler öğrencinin örgün eğitime devamını engelleyebilmektedir.

Ö-22: “Bu şans çok iyi oldu okuyabileceğiæ:” ifadesiyle örgün eğitim koşulları kapsaminda okuyamayan bir öğrencinin açı öğretim yoluyla okuma şansı bulduğunu ifade etmektedir.

Ö-31: "Anneannem fels geçirdiği için okulu birakmak zorunda kaldim."

Ö-54: “Örnek: Kıəların okutulmaması.” ifadesi hâlihazırda ve yakın geçmiște kız çocukların örgün eğitim çağında okumaları önündeki engellerin bölgede sosyolojik bir sorun olmaya devam ettiğini ortaya koymaktadır.

Ö-91: "Sistem böyle devam ettikģe nice gencler açle ögretime yönelmeye devam edecek.".

Öğrenci ifadeleri, öğrencilerin ailevi, çevresel-toplumsal, sosyo-ekonomik koşullar nedeniyle örgün eğitimden kopma gerekçelerini ortaya koymaktadır. Bu çerçevede, mesleki örgün eğitim bünyesinde öğrencilerin sorunlarını karşılayabilecek kapsamlı çözümlere ihtiyaç olduğu söylenebilir.

\section{2.İkinci Alt Amaca İlişkin Bulgular}

Araştırmanın ikinci alt amac1, "Mesleki açı öğretim lisesi öğrencilerini bu kurumda öğrenim görmeye motive eden unsurlar nelerdir?” biçimindeydi. Bu alt amaca ilişkin olarak "Kişisel Sebepler", "Çevresel Sebepler" ve "Diğer Sebepler" olmak üzere 3 tema oluşturulmuş ve her tema altındaki frekanslar sırasıyla Tablo 8, Tablo 9 ve Tablo 10'da sunulmuştur.

Tablo 8. Kişisel sebepler

\begin{tabular}{|c|c|}
\hline Kodlar & $\begin{array}{c}\text { Frekans } \\
\text { (f) }\end{array}$ \\
\hline Meslek sahibi olma isteği & 20 \\
\hline Kolay olduğunu düşündüğü için & 16 \\
\hline Sevdiği mesleği okumasi & 9 \\
\hline Pişmanlık & 9 \\
\hline Kendini geliştirme ve gerçekleştirme & 9 \\
\hline Hayallerini gerçekleştirme & 9 \\
\hline Üniversiteye gitme isteği & 7 \\
\hline Kendi ayaklarının üzerinde durma & 7 \\
\hline Diploma alma isteği & 7 \\
\hline Okuma isteği & 7 \\
\hline Avantajlı olduğu düşünüldüğü için & 5 \\
\hline Hedef & 4 \\
\hline Toplum içinde sayg1 görmek & 3 \\
\hline Rahatlik & 3 \\
\hline Mutlu olmak & 3 \\
\hline İkinci meslek için & 2 \\
\hline Evden çıkma isteği & 2 \\
\hline Sosyal aktiviteye zaman kalması & 2 \\
\hline Farklı ortamda bulunma isteği & 1 \\
\hline Vasiyeti yerine getirme & 1 \\
\hline Özgüvenli olma & 1 \\
\hline Özenmek & 1 \\
\hline İnat & 1 \\
\hline Okuldan atılma & 1 \\
\hline Başarı elde etme & 1 \\
\hline Toplam & 131 \\
\hline
\end{tabular}


Tablo 8'de görüldüğ̈ gibi, toplam 131 öğrencinin ifadesinde açık öğretim lisesinde öğrenim görmeye motive eden unsurlar olarak kişisel gerekçelerle karşılaşılmıştır. Bunlardan 20'si meslek sahibi olma isteği, 16's1 kolay olduğunu düşünme, 9’u sevdiği mesleği öğrenme, 9'u pişmanlık duygusu, 9'u kendini geliştirme ve gerçekleştirme, 9'u hayallerini gerçekleştirme, 7'si üniversiteye gitme isteği, 7'si kendi ayaklarının üzerinde durma, 7'si diploma alma, 7'si okuma isteği, 5'i avantajlı bulma, 3'ü toplum içinde sayg1 görme, 3'ü rahatlık, 2'si ikinci bir meslek edinme, 2'si sosyal aktiviteye zaman kalması, 1'i vasiyeti yerine getirme, 1'i özgüvenli olma, 1'i inat, 1’i okuldan atılma gibi sebeplerle örgün eğitimden ayrllarak mesleki açı öğretim lisesine yöneldiğini ifade etmiştir. Kişisel sebeplerin çok çeşitlenmiş olması mesleki açık öğretim sistemi bakımından sevindiricidir. Bu durum, mesleki açık ortaöğretimin pek çok kişisel ihtiyaca cevap verebilen esnek bir kurumsal yapıya sahip olduğu biçiminde yorumlanabilir.

Öğrencileri mesleki açık lise öğrencisi olmaya motive eden çevresel sebepler Tablo 9'da sunulmuştur.

Tablo 9: Çevresel sebepler

\begin{tabular}{lc}
\hline Kodlar & $\begin{array}{c}\text { Frekans } \\
\text { (f) }\end{array}$ \\
\hline Ailenin isteği & 8 \\
Mecburiyet & 8 \\
Arkadaş çevresi & 6 \\
Aileye destek olma & 4 \\
Okul ortamı & 3 \\
Hayatın zorlukları & 2 \\
\hline Toplam & $\mathbf{3 1}$ \\
\hline
\end{tabular}

Tablo 9'da görüldüğü gibi, toplam 31 öğrencinin ifadesinde mesleki açık liseye yönelmeye motive eden çevresel sebeplerle karşılaşılmıştır. Bunlardan 8'inde ailenin isteği, 8'inde mecburiyet, 6'sında arkadaş çevresi, 4'ünde aileye destek olma, 3’ü okul ortamı, 2'sinde de hayatın zorlukları mesleki açık lise öğrencisi olmanın çevresel motivasyon kaynakları olarak ifade edilmiştir.

Tablo 10: Diğer sebepler

\begin{tabular}{lc}
\hline Kodlar & $\begin{array}{c}\text { Frekans } \\
\text { (f) }\end{array}$ \\
\hline Sınavsız geçiş hakkının olması & 5 \\
\hline Toplam & $\mathbf{5}$ \\
\hline
\end{tabular}

Tablo 10'da görüldüğü gibi, diğer sebepler çerçevesinde 5 öğrenci sınavsız geçiş hakkının olmasını mesleki açı öğretim lisesine yönelmenin motivasyon kaynağı olarak ifade etmiştir. Mesleki açık lisede öğrenim görmeye motive eden unsurlara ilişkin bazı öğrenci görüşleri şöyledir.

Ö-25: "Gelecekteki çocuklarma daha faydal bir anne olmak."

Ö-42: "Okumayarak bir yere varmayacağım düşündüğ̈̈m için."

Ö-43: "Okulumu okuduğum zaman ilerde güzel bir geleceğgim olacağın düşündüm. Zararn neresinden dönersen karder."

Ö-45: "Önemli olan şey çalısan insan bir yere varr."

Ö-66: "Bir baltaya sap olabilmek."

Ö-113: "Hayatımda yaptrğım bu büÿ̈le hatay (okulu brrakmak) açle ögretimle telafi etmek istiyorum."

Ö-120: "Annemi kaybettim ve annem okumam çok istiyordu bir nevi dileğini yerine getirmek istiyorum."

Ö-141: "Kendi yaşımdaki insanlardan büÿ̈̈k insanlar görünce motivem artt."

Ö-143: "Okumak her yașta ve her koșulda güzeldir."

Öğrenci görüşlerinden hareketle, mesleki açı lise öğretiminin örgün eğitime devam etmede çeşitli sorunlar yaşayan öğrenciler için önemli bir alternatif oluşturduğu ve bu öğrencilerin bir ksımının eğitim hayatına tutunmak amacıyla bu imkânı değerlendirmeye çalıştı̆̆ söylenebilir.

\section{3. Üçüncü Alt Amaca İlişkin Bulgular}

Araştırmanın üçüncü alt amacı, “Açık öğretimin örgün eğitime göre avantajları nelerdir?” biçimindeydi. Bu alt amaca ilişkin öğrenci görüşlerinden elde edilen bulgular sırasıyla "Kişisel Avantajlar”, "Okul Kaynaklı 
Avantajlar" ve "Diğerleri” temalanı altında derlenmiștir. Her tema altındaki frekanslar sırasıyla Tablo 11, Tablo

12, Tablo 13 'te sunulmuştur.

Tablo 11: Kişisel avantajlar

\begin{tabular}{lc}
\hline KOD & FREKANS \\
\hline Hem çalışı hem okumak & 27 \\
Eğitimi tamamlamak için firsattır & 6 \\
Kendine daha fazla zaman ayırmak & 5 \\
Sinavlara evde hazırlanmak & 4 \\
Evliyken okuyabilmek & 4 \\
Daha rahat olmak & 3 \\
Maddi durumun iyi olmaması & 3 \\
Meslek seçimi avantajı & 1 \\
Arkadaş ortamına daha çok zaman ayırmak & 1 \\
\hline Toplam & $\mathbf{5 4}$ \\
\hline
\end{tabular}

Tablo 11'de görüldüğü gibi, açı öğretimin örgün eğitime göre avantajları arasında kişisel avantajlara toplam 54 öğrencinin ifadesinde rastlanmıştır. Bunlardan 27'sinde hem çalışıp hem okuma, 6'sında eğitimi tamamlama firsatı, 5'inde kendine daha fazla zaman ayırma, 4'ünde evliyken okuyabilme, 4'ünde sinavlara evde hazırlanma, 3'ünde daha rahat olma, 3'ünde maddi durumun iyi olmaması, 1'inde meslek seçimi avantaj1, 1’inde arkadaş ortamına daha çok zaman ayırma ifadeleri açıköğretimin sağladığı kişisel avantajlar olarak ileri sürülmüştür.

Tablo 12: Okul kaynaklı avantajlar

\begin{tabular}{lc}
\hline KOD & FREKANS \\
\hline Hafta içi eğitim olmaması & 60 \\
Kıyafet serbestlĭ̆i & 9 \\
Kalınan derslerden muaf olmak & 7 \\
2 yıllık yüksekokula sınavsız geçiş & 4 \\
Yaş sınırlamasının olmaması & 4 \\
Yüz yüze eğitim görülmesi & 3 \\
Disiplin olmaması & 3 \\
Sınıf mevcudunun az olması & 2 \\
Öğretmenlerin daha anlayışlı olması & 2 \\
Sinavların test şeklinde olması & 1 \\
Sayısal derslerin olmaması & 1 \\
Yılda 3 defa sinava girmek & 1 \\
Ders ortalamasının düşük olması & 1 \\
\hline Toplam & $\mathbf{9 8}$ \\
\hline
\end{tabular}

Tablo 12'de görüldüğü gibi, açık öğretimin örgün eğitime göre avantajları arasında okul kaynaklı avantajlara toplam 98 öğrencinin ifadesinde rastlanmıştır. Bu ifadelerden 60'ında hafta içi eğitim olmaması, 9'unda kıyafet serbestliği, 7'sinde kalınan derslerden muaf olunması, 4’ünde yaş sınırlamasının olmaması, 3'ünde disiplin olmaması, 2'sinde sınıf mevcudunun az olması, 2'sinde öğretmenlerin daha anlayışlı olması, 1'inde sınavların çoktan seçmeli test şeklinde olması, 1'inde sayısal derslerin olmaması biçimindeki ifadeler açık öğretimin okul kaynaklı avantajları olarak ileri sürülmüştür.

Tablo 13: Diğerleri

\begin{tabular}{lc}
\hline KOD & FREKANS \\
\hline Bir avantaj1 yok & 8 \\
\hline Toplam & 8 \\
\hline
\end{tabular}

Tablo 13’te görüldüğ̈u gibi, 8 öğrenci aç1k öğretimin örgün eğitime göre herhangi bir avantajı olmadığını ifade etmiştir.

Açı öğretimin avantajlarına ilişkin bazı öğrenci görüşleri şöyledir:

Ö-1: Hem okul okuyup hem de işe gitmek.

Ö-8: Hafta içi her gün okula gelmemek.

Ö-21: Kaldiğımı derslerden muaf olabilmemiz:

Ö-22: Hafta sonu ve hafta içi işlerimi hallediyorum, çok güzel, hem geziyorum hem okuyorum.

Ö-23: Okula daha az zaman ayırma, daha rahat olma.

Ö-86: Pek. bir avantajimiz yok ama yine de örgün eğitimden daba iyi .

Ö-108: Okula sivil gelmek.

Ö-112: Hafta sonu gelip daba az ders görmek.

Öğrenci ifadeleri çerçevesinde öğrencilerin açı öğretim sırasında “çalışarak okuyabilmeleri” ve "kendilerine ve arkadaşlarına daha fazla vakit ayırabilmeleri” gibi zamanla ilgili olanaklar öğrenciler tarafindan öne çıkarılan avantajlar olarak değerlendirilebilir.

\subsection{Dördüncü Alt Amaca İlişkin Bulgular}


Araştırmanın dördüncü alt amac1, “Açık öğretimin örgün eğitime göre dezavantajları nelerdir?” biçimindeydi. Bu alt amaca ilişkin öğrenci görüşlerinden elde edilen bulgular sırasılyla "Okul Kaynaklı Dezavantajlar", "Çevresel-Toplumsal Dezavantajlar" ve "Diğerleri” temaları altında derlenmiştir. Her tema altındaki frekanslar sırasıyla Tablo 14, Tablo 15, Tablo 16'da sunulmuştur.

Tablo 14: Okul kaynaklı dezavantajlar

\begin{tabular}{lc}
\hline KOD & FREKANS \\
\hline Kültür derslerinin olmaması & 28 \\
Hafta içi ders görmemek & 20 \\
Ders saatlerinin az olması & 20 \\
Yüz yüze eğitim görmemek & 11 \\
Kültür derslerinden sınav olmak & 9 \\
Disiplinsizlik & 7 \\
Bilgi yetersizliği & 4 \\
Bilginin kalıcı olmaması & 4 \\
Rapor alınmaması & 3 \\
Her dönem para istenmesi & 3 \\
Yılda 3 defa sinav olmak & 1 \\
Açıktan okuyanların sayıca çok olması & 1 \\
Puan sinırlamasının olmaması & 1 \\
\hline Toplam & $\mathbf{1 1 3}$ \\
\hline
\end{tabular}

Tablo 14’te görüldüğü, gibi toplam 113 mesleki açı öğretim öğrencisinin ifadesinde okul kaynaklı dezavantajlar ileri sürdükleri bulunmuştur. Bunlardan 28'inde kültür derslerinin olmaması, 20'sinde hafta içi ders görmeme, 20'sinde ders saatlerinin az olması, 11'inde yüz yüze eğitim görmeme, 9'unda kültür derslerinden yüyüze ders almaksızın sınav olma, 7'sinde disiplinsizlik, 4'ünde bilgi yetersizliği, 4'ünde bilginin kalıcı olmaması, 3'ünde her dönem para istenmesi, 1'inde yılda 3 defa sınav olma, 1'inde açıktan okuyanların sayıca çok olması, 1'inde de puan sınırlamasının olmaması ifadeleri açık öğretimin örgün eğitime göre dezavantajları olarak ifade edilmiştir.

Tablo 15: Çevresel-toplumsal dezavantajlar

\begin{tabular}{lc}
\hline KOD & FREKANS \\
\hline Açı öğretim diplomasının küçümsenmesi & 2 \\
Toplumun kötü bakış açısı & 1 \\
\hline Toplam & $\mathbf{3}$ \\
\hline
\end{tabular}

Tablo 15’te görüldüğü gibi, toplam 3 öğrencinin ifadesinde çevre kaynaklı dezavantajlar ile karşılaşılmıştır. Bu öğrencilerden 2'si açık öğretim diplomasının küçümsenmesini, 1’i de toplumun kötü bakış açısını açık öğretimin çevre kaynaklı dezavantajları olarak ifade etmişlerdir.

\begin{tabular}{lc} 
Tablo 16: Diğerleri & \\
\hline KOD & FREKANS \\
\hline Hafta sonu aileyle vakit geçirememek & 1 \\
\hline Toplam & $\mathbf{1}$ \\
\hline
\end{tabular}

Tablo 16'da görüldüğü gibi, bir öğrenci kişisel beklentileri çerçevesinde bir dezavantajı ileri sürmüştür. Bu öğrenci hafta sonu ailesiyle vakit geçirememeyi açı öğretimin dezavantajı olarak ifade etmiştir.

Aşağıda açık öğretimin dezavantajlarına ilişkin bazı öğrenci görüşlerine yer verilmiştir:

Ö-18: Tüm derslerin yüz yüzze olmaması.

Ö-34: Hafta içi ders görmememiz.

Ö-45: Normal eăitimde verilen disiplin, ders tam olarak bize verilmiyor.

Ö-46: Daba a乏 eğitim görïyoru₹...

Ö-107:Şimdi gençlere bir tavsiyede bulunacam baž seyleri vaktinde değerlendirmek ve değerini

kavramak sok daha iyi.

Ö-119:Her dönem para istiyor. Paramı yoktur.

Ö-109:Kültür derslerini görmeden sinavda kültür dersleriyle ilgili sinav olmamı:

Ö-141:Açle liseye geldiüzimde toplumun niye okuyorsun vb. gibi sorular.

Öğrenci ifadelerine göre açık öğretimin dezavantajları ağırlıklı olarak okul kaynaklıdır. Derslerin yüz yüze olmaması, daha disiplinsiz ve yetersiz eğitim, her dönem para istenmesi gibi açık öğretimin uygulanış biçimi ile ilgili sorunların öğrenciler tarafından ileri sürülen başlıca dezavantajlar olduğu bulunmuştur. 


\section{TARTIŞMA VE SONUÇ}

Mesleki açık lise öğrencilerinin örgün eğitim dışında olma nedenlerinin araştırıldığı bu çalışmada ulaşılan bulgular çerçevesinde varılan sonuçlar aşağıda sunulmuş ve tartışılmıştır.

Mesleki açık öğretime yönelme nedenleri olarak okul kaynaklı, kişisel ve çevresel/toplumsal gerekçelerle karşılaşılmışır. Bunlardan okul kaynaklı sebepler arasında okulun uzak olması, okulla ilgili olumsuz izlenimlere sahip olunması gerekçeleri ön plâna çıkmıştır. Kişisel sebepler arasında başarısızlık, okula karşı ilgisizlik nedenleri vurgulanmıştır. Çevresel sebepler arasında ise özellikle aile içi sorunlara ve arkadaş çevresinden kaynaklanan olumsuzluklara değinilmiştir. Taylı (2008) alanyazındaki araştırmalardan derlediği çalışmasında, okulu bırakma nedenleri arasında akademik başarısızlığı ve buna yol açan sebepleri öne çıkarmıştır. Bu çerçevede öğrencinin akran grubunun özellikleri, öğrencinin bu gruptaki liderliği ve de arkadaş grubunun akademik basarısı ile ögrencinin okulu bırakma olasıllğı arasında sıkı bir ilişki olduğunu vurgulamıştır. Christle, Jolivette ve Nelson (2007) tarafindan yapılan bir başka çalısmada, okulu bırakmayı etkileyebilen okulla ilgili değişkenler incelemiştir. Çalışma sonucunda okuldaki öğrenci sayısı, öğrencilerin ailelerinin sosyoekonomik düzeyleri, okulun genel akademik başarı ortalaması, öğrencilerin okula devam oranı, sınıf tekrarı oranı, öğrencilerin okuldan uzaklaşma oranı, okuldaki şiddet oranı, yasal işlem gereken şiddet oranı ve öğrencilerin bir sonraki basamağa başarılı bir şekilde hazırlanamamaları okulu bırakmayı etkileyebilen değişkenler olarak tespit edilmiştir. Alanyazındaki çalışmalarda okul terki ile ilişkili değişkenlerin önemli bir bölümünün eğitim kurumlarındaki örtük programlar ile ilişkili olduğu söylenebilir.

Eğitim kurumunun yapısını ve öğrencilerin bu yapı ile uyumunu anlamada, resmi program ile birlikte bireylerin sosyo-kültürel özellikleri ile şekillenen örtük programın dikkate alınmasına ihtiyaç vardır (Demir ve Duruhan, 2015:33). Okul terki bakımından kurumların örtük programları irdelenmelidir. Öğrenciyi çevreleyen eğitim ortamının, öğretmenlerin, idarecilerin, arkadaş çevresinin, ailenin, toplumsal yapının vb. öğrencilere verdiği mesajlar, telkinler ve diğer etkiler takip edilmeli ve mümkünse kontrol edilmelidir. Böylece, okul terkine meyilli öğrencilerin önceden tespit edilmesi ve önleyici tedbirler geliştirilmesi daha mümkün olabilir. Bu bağlamda disiplin kayıt defterleri de bir veri kaynağı olarak kullanılabilir. Akpınar ve Özdaş (2013:24), 8 lisenin disiplin defterlerini inceledikleri çalışmalarında disiplin suçu işleyen öğrencilere en sık olarak okuldan kısa süreli uzaklaştırma cezasının verildiğini tespit etmişlerdir. Bu ceza türünün öğrencileri derslerden daha fazla uzaklaştırarak okul terki için zemin hazırlayabileceği göz önünde tutulmalıdır. Bu durumda olan öğrencilerin sorunlu davranışlarının nedenlerinin daha iyi etüt edilmesine ve sorun çözen uygulamalara gidilmesine ihtiyaç olduğu söylenebilir. Benzer biçimde Adıyaman (1997), Açık öğretim Lisesi (AÖL) öğrencilerinin öğrenimlerini yarıda bırakma nedenlerini incelediği çalışmasında, öğrenimi terk etme nedenleri olarak kişisel nedenlere yönetsel ve yapisal sorunlara dikkat çekmiştir.

Okul terki vakalarında öne çıkan faktörlerden biri de akademik başarı sorunudur. Ülkemizde mesleki liselere akademik başarı ortalaması düşük bireylerin yerleştiği bilinmektedir. Özkahveci ve Ulusoy (2002), mesleki açık öğretim öğrencileri ile örgün kız meslek lisesi öğrencilerinin başarılarını kıyasladığı çalışmasında örgün eğitimin kendisinden beklenen başarıyı üretemediği sonucuna ulaşmıştır. Bu gibi durumlar, öğrenciler ve veliler nazanında kurumla ilgili olumsuz algıya yol açmaktadır. Sağlık Meslek Liselerini inceleyen bir başka çalışmada öğrencilerin başarı durumlarının kötü oluşunun umutsuzluk düzeylerini artırdığı bulunmuştur (Aydın vd., 2013). Binici ve Arı (2004:385), çalışmalarında Ülkemizdeki eğitimin eleme yöntemine dayandığını ve başarılı olamayanların devre dışı kaldığını, gelişmiş ülkelerde ise okul-sanayi destekli programlar çerçevesinde elemeye dayalı olmaksızın her bireyin yararlı olabileceği alanın tespit edilerek yönlendirildiği bir anlayışın esas alındığını belirtmişlerdir. Bu bakımdan örgün mesleki eğitimde de bireyleri başarılı-başarısız doğrultusunda ayırmak yerine her bireyi en işlevsel bir biçimde etkin kılma noktasında değerlendirebilen iş-okul modelleri kurmanın faydalı olacağı söylenebilir.

Bu çalışmada öğrenciler, mesleki açık öğretim yoluyla sağlanan bazı motive edici unsurlara değinmişlerdir. Mesleki açık lise öğrencileri örgün liselerdeki öğrencilere göre kendilerine daha fazla zaman ayırabildiklerini ve bundan memnun olduklarını ifade etmişlerdir. Sarıhan (2010), çalışmasında mesleki açık lise öğrencilerinin çoğunlukla 18-21 yaş aralı̆̆ında, bir kısmının çalısıp okuyarak yarım kalan eğitimlerini tamamlamayı 
amaçladıklarını saptamıştır. Eğitim sistemi içerisinde mesleki eğitim, bireylerin koşulları ve toplumsal ihtiyaçlar için en esnek çözümleri üretebilmeli ve öğrencilerin nitelikli işgücü unsurları olarak topluma katılımını sağlayabilmelidir. Mesleki örgün eğitimin süreç olarak iş günlerinin tamamına ve sabahtan akşama dek günün bütününe yayılan yapısının staj süreçleri dışında öğrencilerin gerçek mesleki gözlemler yapmalarını ve iş sahalarında mesleki deneyimler elde etme imkânlarını sınırladığı söylenebilir. Bundan başka bu çalışmada, 131 öğrenci mesleki açık lisede öğrenim görmeye meslek sahibi olma, kolay olduğunu düşünme, kendini geliştirme, meslek yüksekokullarına sınavsız yerleşme gibi kişisel gerekçelerle motive olduklarını belirtmişlerdir. 31 öğrenci ise mesleki açık liseye mecburiyet ve arkadaş çevresi gibi çevresel sebepler ile yöneldiklerini ifade etmiştir. Çalışmada, mesleki açık liselere daha çok kişisel sebeplerle yönelme olduğu bulunmuştur. Bu durum, mesleki açık liselerin örgün eğitim dışında kalan bireyler için farklı kişisel ihtiyaçları karşılama konusunda işlevsel bir program sağladığ1 şeklinde yorumlanabilir.

Öğrenciler, mesleki açık öğretimin örgün öğretime göre sağladığı avantajlar çerçevesinde kişisel ve okul kaynaklı avantajları ön plana çıkarmışlardır. Kişisel avantajlar kapsamında öğrencilerin 27’si hem çalışıp hem okuma, 6'sı eğitimini tamamlama, 5'i kendine daha fazla zaman ayırma, 4'ü ise evliyken okuyabilme avantajlarını ifade etmişlerdir. Mesleki açık öğretimin sağladığı okul kaynaklı avantajlara ise 98 öğrenci ifadesinde rastlanmıştır. Bu öğrencilerden 60'1 hafta içi eğitim olmaması, 9'u kıyafet serbestliği, 7'si kalınan derslerden muaf olma sebebiyle örgün eğitimden ayrıldığını ifade etmiştir. Bu noktada "çalışarak okuyabilme" imkânının mesleki örgün eğitim bünyesinde sağlanamaması dikkat çekicidir. Örgün mesleki eğitim bünyesinde zorunlu staj uygulamaları olsa bile öğrenci açısından "çalışarak okumanın” hem deneyim hem de gelir bakımından nispeten daha fazla kazanımlar sağladığı söylenebilir. Soylu da (2014:84) mesleki açık lise muhasebe bölümü öğrencileri ile gerçekleştirdiği çalışmasında öğrencilerin büyük bölümünün dar gelirli olduğunu ve öğrencilerin çoğunun mesleki eğitimlerinin son yıllarında eğitimlerini çeşitli nedenlerle tamamlayamadıklarını saptamıştır. Özellikle dar gelirli öğrenciler için döner sermaye uygulaması öğrencilere mesleki eğitim bünyesinde okurken çalışma imkânı sağlamaktadır. Bu durumda öğrencinin eğitim çatısı altında gerçek iş deneyimiyle buluşması ve bir kazanç elde etmesi mümkün olmaktadır. Döner sermaye uygulamasının sağlayabileceği bir başka avantaj da öğrenme sürecinde öğrencilerin daha aktif hale gelmeleridir. Mesleki eğitimde öğrenmeye karşı bir direnç olduğu birçok eğitici tarafindan bilinmektedir. Bunun nedenleri arasında, veilen eğitimlerde, dinleyicilerin hep pasif tarafta kalması ve verilen eğitimlerin sıkıcı ve anlaşılmaz olması sayılabilir (Binici ve Arı, 2004:384). Dolayısıyla, örgün mesleki eğitimde döner sermaye uygulamasının önemli bir olanak olduğu söylenebilir. Ancak, ne yazık ki bu uygulama henüz yeterince yaygınlaşmamıştır.

Çalışmada mesleki açı öğretimin örgün öğretime göre dezavantajlı yönlerini ortaya koyan 113 öğrenci ifadesiyle karşılaşılmıştır. Bu dezavantajlar, okul kaynaklı ve çevresel olmak üzere iki sınıfta toplanmıştır. Okul kaynaklı dezavantajlar çerçevesinde kültür derslerinin yüzyüze olmaması ve kültür ders saatlerinin az olması ön plâna çıkarılan dezavantajlardır. Mesleki açık öğretim lisesi öğrencileri, mesleki dersler dışında kalan kültür derslerini yüz yüze almadıkları için öğrenme güçlükleri yaşadıklarını vurgulamışlardır. Benzer olarak Yavuz (2014), mesleki açık öğretim lisesi öğrencilerinden elde ettiği veriler çerçevesinde öğrencilerin yüz yüze eğitim görmeleriyle dışsal ve içsel motivasyonları arasında pozitif yönde bir ilişki olduğunu bulmuştur. Yine Soylu (2014:85) çalışmasında mesleki açı öğetim lisesi öğrencilerinin yüzyüze eğitim olanaklarının geliştirilmesini istediklerinin belirlemiştir. Çevresel/toplumsal dezavantaj olarak da 3 öğrenci ifadesinde açık öğretim diplomasının toplum tarafindan yeterince değerli bulunmaması gösterilmiştir. Yine Şentürk (2009:90), çalışmasında mesleki açı lise öğrencilerinin kendilerine sağlanan yazılı ve basılı materyaller, bilişim ortamları ve yeterlilikleri, eğitim programlarının nitelikleri ve uygulama süreci, akademik danışmanlık, destek ve diğer hizmetlerle ilgili olumsuz görüşler ileri sürdüklerini bulmuştur. Hem bu çalışma hem de alanyazındaki benzer çalışmalardan hareketle mesleki açık öğretimin "eğitim kalitesi” bakımından değil de öğrenciler için sağladığı "esnek koşullar" yönüyle tercih edildiği bunda da daha çok yarım kalan eğitimi tamamlamanın başlıca olduğu söylenebilir.

Bu çalışmada dikkati çeken diğer bir tespit kimi öğrencilerin açık öğretim konusunda olumlu gördükleri bazı hususları diğer bir kısım öğrencinin dezavantaj veya olumsuzluk olarak değerlendirmesidir. Bu tezat 
durum, bazı öğrencilerin kendi istekleri ve/veya olumlu motivasyon kaynakları ile diğer bazı öğrencilerin ise firsat eşitsizliği bağlamında çeşitli zorunluluklar nedeni ile mesleki açı öğretime yönelmiş olmalarından kaynaklanıyor olabilir. Öğrencilerin okul hayatlarında içinde bulundukları olumsuz sosyo-ekonomik koşulların mağduru olmamaları için gereken mücadeleyi vermek toplumsal bir ödev kabul edilmelidir. Bu çalısma ve benzer çalışmalarda ulaşılan bulgular sşığında, mesleki örgün eğitimin ve mesleki açık öğretimin özellikle firsat eşitsizliği mağduru bireylerin ihtiyaçlarını karşılamaya dönük olarak geliştirilmesi gerektiği söylenebilir. Buna yönelik olarak başta Aile ve Sosyal Politikalar Bakanlığı olmak üzere, sivil toplum kuruluşları, meslek odaları, mesleki konfederasyonlar ve ilgili tüm diğer kurum ve kuruluşlar Milli Eğitim Bakanllğı ile güçlü bir işbirliği yapmalıdır. Bu paydaşların birlite alacağı ve uygulayacağı tedbirler ile mesleki örgün eğitim süreci bireylerin farklı ihtiyaçlarına cevap verebilecek hale getirilmeli, özellikle sosyo-ekonomik koşullar yönünden mağdur durumdaki gençlerin mesleki örgün eğitim alma ve sürdürme olanakları desteklenmelidir.

Çalışmanın nihai sonucu olarak, açık öğretim liselerine yönelmenin özellikle firsat eşitsizliği mağduru bireylerin eğitim hayatlarının sürekliliğine yönelik bazı firsatlar sağladığı ancak yine de bu sorunla daha geniş bir tabanda ve daha güçlü bir işbirliği ile mücadele edilmesi gerektiği, ayrıca örgün eğitimin döner sermaye, esnek süreç yönetimi, iş ve mesleki sorumluluk temelli eğitim gibi uygulamalarla kazanç edinmeye imkân veren, rekabetçi anlayış ve gerçek mesleki deneyimlerle öğrencileri daha fazla buluşturan bir yapıya kavuşturulması halinde daha fazla öğrencinin örgün yapı içinde kalabileceği değerlendirilmektedir.

Çalışma sonuçlarına dayalı olarak hem mesleki örgün hem de mesleki açık liseler için şu öneriler geliştirilmiştir.

$\checkmark$ Örgün eğitim sisteminde başarısızlık, disiplin vb. sorunlar sebebiyle açık öğretime yönelen öğrencilerin bu konuda yaşadıkları güçlüklerin iyi analiz edilmesine ve örgün eğitim sisteminin bu açılardan iyileştirilmesine ihtiyaç duyulmaktadır. Bu çerçevede, mesleki açık öğretimi örgün eğitime göre daha cazip kılan olanakları örgün eğitim bünyesinde toplayarak örgün eğitim dışına çıkmayı azaltacak yeni bir meslek lisesi modeli geliştirilebilir.

$\checkmark$ Döner sermaye faaliyetlerinin örgün mesleki eğitim liselerinin tümüne yaygınlaştırılmasına yönelik tedbirler alınmalı, böylece daha fazla öğrencinin mesleği iş başında öğrenmelerine ve ürettikleri iş üzerinden kazanç elde etmelerine imkân verilmelidir.

$\checkmark$ Mesleki açı öğretim lisesi öğrencilerinin yüz yüze kültür dersleri almalarına ilişkin tedbirler alınmalıdır. Bununla birlikte, açık öğretim liselerinin kendi müstakil okul binaları ve öğretmenlerinin olması halinde örgün eğitim okullarında gölge gibi eğitim görmekten kurtulmaları mümkün olabilecektir

$\checkmark$ Milli Eğitim Bakanlığı ile Aile ve Sosyal Politikalar Bakanlığı arasında öğrecilerin firsat eşitsizliği nedeniyle örgün eğitim çatısı dışına çıkmalarının önüne geçmek amacıyla öğrencilerin sosyal koşullarını incelemeyi, kritik durumdaki öğrencilerin durumlarını Aile ve Sosyal Politikalar Bakanlığına raporlayarak sosyal koşullar bakımından desteklenecek öğrencileri saptamayı ve bu konuda çeşitli tedbirleri ve uygulamaları geliştirmeyi içeren bir protokol düzenlenebilir. Bu protokol çerçevesinde öğrencilerin sosyal eşitsizlikleriyle yerinde ve zamanında mücadele etmek amacıyla örgün eğitim kurumlarında Aile ve Sosyal Politikalar Bakanlığına bağlı birer aile sosyoloğu görevlendirilebilir.

\section{KAYNAKÇA}

Adıyaman, Z. (1997). Açık ögretim Lisesi Öğrencilerinin Öğrenimi Terk Etme Nedenleri ve Öneriler. (Yayımlanmamış Yüksek Lisans Tezi). Ortadoğu Üniversitesi, Ankara.

Akpınar, B. \& Özdaş, F. (2013). Lise Disiplin Sorunlarının Cinsiyet Değişkeni Açısından İncelenmesi, Dicle Üniversitesi Ziya Gökalp Eğitim Fakültesi Dergisi, 21, 20-29.

Aydın, M., Erdoğan, S., Yurdakul, M. \& Eker, A. (2013). Sağlık Yüksekokulu ve Sağlık Meslek Lisesi Öğrencilerinin Umutsuzluk Düzeyleri, Süleyman Demirel Üniversitesi Sağglk Bilimleri Dergisi, 4(1), 1-6.

Binici, H. \& Arı, N. (2004). Mesleki ve Teknik Eğitimde Arayışlar, Gaz̨i Eğitim Fakültesi Dergisi, 24(3), 383-396.

Chistle, C.A., Jolivetti, K. \& Nelson, M. (2007). School Characteristics Related to High School Dropout Rates. Remedial and Special Education, 28(6), 325-339. 
David, M. \& Reid, I. (2007). Social Inequality and Education- Education and Society, (Ed. Barton, L.), USA:New York, Routledge Publication.

Demir, O. \& Duruhan, K. (2015). Psikolojik Danışma ve Rehberlik Programı'nda Örtük Program Algısı (İnönü Üniversitesi Örneği): Bir Durum Çalışmas1, Journal of Computer and Education Research, 3(6), 32-70.

Doğan, İ. (2004). Toplum ve Eğitim Sorunlar Üzerinde Felsefi ve Sosyolojik Tabliller. Ankara: Pegema Yayıncilık.

Erden, M. (2001). Öğretmenlik. Mesleğine Giriş. İstanbul: Alkım Yay.

French, D.C. \& Conrad, J. (2001). School Dropout as Predicted by Peer Rejection and Antisocial Behavior, Journal of Research on Adolescence, 11(3), 225-244.

Krippendorff, K. (2011). Agreement and Information in the Reliability of Coding. University of Pennsylvania Scholarly Commons Departmental Papers Communication Methods and Measures, 5(2), 93-112.

MEB Destek Hizmetleri Genel Müdürlügü Döner Sermaye İşletmeleri. (2015). Döner Sermaye Işsletmeleri Bulunan Okul Listesi, https://dhgm.meb.gov.tr/www/mill-egitim-bakanligina-bagli-doner-sermaye-isletmelerigenel-listesi-04012016/icerik/238, [erişim Tarihi: 10/01/2015].

MEB Milli Eğitim İstatistikleri 2015/16. (2016). Ortaögretim Genel Döküm Tablosu, http://sgb.meb.gov.tr/meb_iys_dosyalar/2016_03/18024009_meb_istatistikleri_orgun_egitim_2015_20 16.pdf, [erişim tarihi: 14.02 .2017 ].

Moran, L. \& Rumble, G. (Ed.) (2004). Vocational Education and Training Through Open and Distance Learning, London and New York: Routledge Falmer.

Özkahveci, Ö. \& Ulusoy, A. (2002). Mesleki Açık öğretim Programı Ve Kız Meslek Lisesi Öğrencilerinin Başarılarının Karşılaştırılması, Eğitim Bilimleri ve Uygulama Dergisi, 1(1), 67-77.

Sarıhan, Ș. (2010). Mesleki Açı Öğretim Lisesindeki Ögrenci Hiæmetlerinin Etkililiğ Konusunda Ö̆grenci GörüsleriAnkara Örneği. (Yayımlanmamış Yüksek Lisans Tezi). Ankara Üniversitesi, Ankara.

Soylu, S. (2014). Mesleki Açık Öğretim Lisesi Mubasebe Eğgitiminde Karşılaşılan Sorunlar ve Cö̈̌üm Önerileri. (Yayımlanmamış Yüksek Lisans Tezi). Gazi Üniversitesi, Ankara.

Sönmez, V. (2002). Eğitim Felsefesi. Ankara: Anı Yayıncılık.

Şentürk, E. (2009). Mesleki Açık Öğretim Lisesi Bilișim Teknolojileri Alannnda Verilen Eğgitimin Etkililiğine Yönelik Ögrrenci Görïşlerinin Değerlendirilmesi. (Yayımlanmamış Yüksek Lisans Tezi). Uludağ Üniversitesi, Bursa.

Şimşek, H. (2011). Lise Öğrencilerinde Okulu Bırakma Eğilimi ve Nedenleri, Eğitim Bilimleri Araştırmalar Dergisi, 1(2), 27-47.

Taş, A., Selvitopu, A., Bora, V. \& Demirkaya, Y. (2013). Meslek Lisesi Öğrencilerinin Okul Terk Nedenleri, Kuram ve Uygulamada Eğitim Bilimleri Dergisi, 13(3), 1551-1566.

Taylı, A. (2008). Eğitim Sisteminde Önemli Bir Sorun: Okulu Bırakma, Türk Psikolojik Danısma ve Rebberlik Dergisi, 3(30), 89-101.

Tezcan, M. (1997). Eğitim Sosyolojisi. Ankara: Anı Yayıncll1k.

TÜBİTAK (2015). 46. Ortä̈gretim Öğrencileri Araștrma Projeleri Yarıșası Proje Rehberi 2015, http://www.tubitak.gov.tr/sites/default/files/2204_proje_kitapcik.pdf _ [erişim tarihi: 04.11.2015].

Wieringen, F. \& Atwell, G. (Ed.) (1999). Vocational and Adult Education In Europe. Dordrecht: Kluwer academic publishers.

Yavuz, H. (2014). Mesleki Açık Öğretim Lisesi Öğrencilerinin Sunulan Hiðmetlerin Etkililiği Konusunda Görüsleri ve Motivasyon Düzeyleri. (Yayımlanmamış Yüksek Lisans Tezi). Fatih Üniversitesi, İstanbul.

Yıldırım, A. \& Şimşek H. (2005). Sosyal Bilimlerde Nitel Araştırma Yöntemleri. Ankara: Seçkin Yayıncılık.

URL-1:

http://tdk.gov.tr/index.php?option=com_gts\&arama=gts\&guid=TDK.GTS.56977df12b0071.16530648, [erişim tarihi: 10.09.2015].

URL-2:

http://mevzuat.meb.gov.tr/html/2236_0.html [erişim tarihi: 13.09.2015].

URL-3:

http://maol.meb.gov.tr/sites/default/files/dokumanlar/mesleki_acik_ogretim_lisesi_yonetmeligi_0.pdf, [erişim tarihi: 14.09 .2015$]$.

\section{Citation Information}

Sözer, Y. (2017). Mesleki Açık Öğretim Lisesi Öğrencilerinin Örgün Eğitim Dışında Olma Nedenlerine İlişkin Görüşlerinin Değerlendirilmesi. Dicle Üniversitesi Ziya Gökalp Eğitim Fakültesi Dergisi, 30, 493-507. 